\title{
EDITORIAL
}

\section{ONDE PUBLICAR?}

Um dos aspectos da medicina brasileira que sempre me pareceu estranho é a importância que se dá em publicar em revistas fora do Brasil. Isto não é uma característica dos serviços médicos coloniais, quer da Inglaterra quer da França na África. Os franceses com sua forte escola de medicina em Dakar publicavam no Bulletin d'Afrique Noir (Alas Defunct). Os ingleses tinham as revistas médicas West African, East African e Central African, bem como a South African Medical Journal. Minhas primeiras publicações surgiram principalmente nessas revistas. Por que? Porque elas eram as mais pertinentes à área em questão.

Na verdade, a importância de uma publicação não depende de onde ela é publicada. Atualmente, com a Internet, essas revistas fontes são ainda mais acessíveis. A decisão sobre onde publicar, que fica a cargo do autor principal, dependerá de onde a contribuição for de maior utilidade. Regimes políticos corruptos na África (Amin, Mobutu) prejudicaram a literatura médica africana, apesar dos esforços da Organização Mundial de Saúde para compensá-la.

Temos sorte aqui no Brasil, não somente pelas suas revistas, como a Revista do Instituto de Medicina Tropical de São Paulo e Memórias do Instituto Oswaldo Cruz (embora esta seja mais biológica), mas porque estabilidade política significa que a ciência aplicada à medicina pode continuar florescendo. Pois aspectos aplicados de tratamento diagnóstico e prevenção requerem observações a longo prazo.

Outra idéia errônea é que a publicação deve ser em inglês. Antes mesmo que eu tivesse começado a trabalhar sobre a doença de Chagas, eu dominava a literatura em espanhol e português. Pois, como dizia T.S. Eliot: "how could I begin". Infelizmente, o chinês não será possível nesta altura da minha vida, mas a revista Chinese Medical Journal é publicada em inglês, exatamente como a Scientific American é produzida em vários idiomas.

Jamais consegui escrever nem mesmo uma carta como esta em menos de cinco tentativas, mais freqüentemente por sugestões dos editores. Onde ela será publicada dependerá de sua relevância.

\section{WHERETO PUBLISH?}

One of the aspects of Brazilian medicine that has always struck me as odd is the value placed on publishing in medical journals outside Brazil. This was not a feature of the colonial medical services either of Britain of France in Africa. The french with their very strong medical school in Dakar published in the Bulletin D'Afrique Noir (Alas Defunct). The English had the West African, East African and Central African medical journals as well as the South African Medical Journal. My early publications mainly appeared in these journals. Why? Because they were most relevant to the area in question.

Really the value of a publication depends not on where it is published. Today with Internet such source journals are even more accessible. The decision of where to publish which rests with the senior author will depend on where the contribution will be of most use. Corrupt political regimens in Africa (Amin, Mobutu) have prejudiced the African medical literature though the World Health Organisation struggles to compensate.

We are fortunate here in Brazil not only because of this journal, the Revista do Instituto de Medicina Tropical de São Paulo and Memórias do Instituto Oswaldo Cruz (though this is more biological) but because political stability means the applied science of medicine can continue to flourish. For applied aspects of diagnosis treatment and prevention require long term observations.

Another fallacy is that it has to be English. Before I even started to work on Chagas' disease I dominated the literature in Spanish and Portuguese. For "how could I begin" as T.S. Eliot says. Unfortunately Chinese will not be possible at my time of life but the Chinese Medical Journal is published in English just as the Scientific American is produced in a series of languages.

I have never managed to write even a letter like this in less than five attempts often more with the editors suggestions. Where it is published depends on its relevance.

\section{Philip Davis Marsden \\ Núcleo de Medicina Tropical e Nutrição \\ Universidade de Brasília \\ Brasília, DF}

Recebido para publicação em 14/01/97. 